Robert A. Zeller, Jr., Hachita, New Mexico

Geologic Controls in Oil and Gas Exploration in Southwestern New Mexico and Southeastern Arizona

In southwestern New Mexico and southeastern Arizona the Paleozoic and Cretaceous sedimentary sections average between 15,000 and 20,000 feet in maximum thickness and consist largely of carbonate rocks. Humble Oil and Refining Company's recent well in southwestern New Mexico demonstrates the presence of oil stain and natural gas in the section. With such a thick sedimentary section and the known presence of oil and gas, the regional potentialities of commercial oil and gas are good.

Successful exploration in the region depends largely on the discovery of sufficient porosity and favorable structural traps. Many stratigraphic units are consistent throughout the region and have low porosity, but others have regional differences, such as the presence of reefs, which favor higher porosity. Lower Cretaceous reefs in the region are distributed erratically, and neither reef trends nor the presence of reefs in the subsurface may be determined without intensive study. Lower Wolfcampian reefs, on the other hand, are more restricted stratigraphically and their trends may be determined. Since all other stratigraphic factors regarding favorable porosity are constant or at present are undetermined in the region, present exploration may best be concentrated in the belt where lower Wolfcampian reefs may be expected.

The location of structural traps requires a fundamental understanding of the structural geology of the region. Two chief structural disturbances affected the region, an early one which in general is correlative with the Laramide orogeny and a later one which is correlative with the Basin-and-Range disturbance. Laramide structures include high-angle faults, large strong folds, and overthrust faults. Basin-and-Range structures include high-angle faults, broad gentle folds, and normal or "block" faults which produced the elevation of the ranges and the depression of the valleys. Basin-and-Range folds are so mild, compared with earlier strong Laramide folds, that their effect on pre-Tertiary rocks is negligible. Laramide anticlines, possibly in combination with later faults, supply the most favorable structural traps. As thick deposits of Tertiary volcanic rocks and of alluvium cover much of the area, the discovery of favorable structures must be based on projection of exposed folds under covered areas and on geophysical techniques.

\title{
AT HOME AND ABROAD
}

V. Zay Smith Associates announce an organjzational change from a partnership to a corporation. The new company is known as V. Zay Smith Associates, Inc., The principals are V. Zay Smith, Curtis L. Buttorff, and Richard L. Hughes. Elmer H. Dunstan and B. Pete Harder, formerly partners, have withdrawn from the company.

J. P. Woons, director of the Geophysical Laboratory of the Atlantic Refining Company in Dallas, Texas, spoke on "Well Logging and Magnetic Tape," at the meeting of the Houston Geological Society, April 1.

Teodoro Diaz-Gonzales, division geologist for the Petroleos Mexicanos, Monterrey, Mexico, gave two lectures at The University of Texas, Department of Geology, March 24-25, on "The Geology of Northern Mexico." Diaz also led a four-day trip for geology students and faculty to northern Mexico including visits to Saltillo, Galeana, and Monterrey. 